\title{
Impact of Front Line Demonstration on the Yield and Economics of Rapeseed under Rainfed Condition in Namsai District of Arunachal Pradesh, India
}

\author{
M. Sonowal Bora ${ }^{1 *}$, D. Sasmal ${ }^{2}$, Debasish Borah $^{3}$ and H. Kalita \\ ${ }^{1}$ Plant protection, ${ }^{2}$ Fishery Science, ${ }^{3}$ Agronomy, ${ }^{4}$ Agriculture Entomology, \\ ICAR-Krishi Vigyan Kendra Namsai, Arunachal Pradesh-792102, India \\ *Corresponding author
}

\begin{tabular}{|c|c|}
\hline & A B S T R A C T \\
\hline $\begin{array}{l}\text { Rapeseed, Yield, } \\
\text { Rainfed, } \\
\text { Technology gap, } \\
\text { Extension gap }\end{array}$ & \multirow{3}{*}{$\begin{array}{l}\text { The present study was conducted continuously during three years from Rabi } 2013- \\
14,2014-15 \text { and } 2015-16 \text { to assess the impact of front line demonstration on the } \\
\text { yield and economics of rapeseed in Namsai District of Arunachal Pradesh. The } \\
\text { improved technologies consisting use of improved variety, sowing method, seed } \\
\text { treatment with trichoderma, balanced biofertilizer application with rhizobium and } \\
\text { PSB culture and integrated pest management. FLD recorded higher yield as } \\
\text { compared to farmer's practice. The average results of three year pooled data } \\
\text { revealed that the front line demonstration on rapeseed recorded an average yield of } \\
9.31 \text { q/ha under demonstrated plots as compare to farmers practice } 6.60 \mathrm{q} / \mathrm{ha} \text {. The } \\
\text { improved technology gave higher gross return, net return with higher benefit cost } \\
\text { ratio than the farmer's practices. }\end{array}$} \\
\hline Article Info & \\
\hline $\begin{array}{l}\text { Accepted: } \\
\text { 24 August } 2020 \\
\text { Available Online: } \\
\text { 10 September } 2020\end{array}$ & \\
\hline
\end{tabular}

\section{Introduction}

Rapeseed is an oil producing plant species under the family Brassicaceae belonging to the order Brassicales and cultivated mainly for its oil-rich seed. It is the third-largest source of vegetable oil in the world. According to the United States Department of Agriculture, rapeseed was the third-leading source of vegetable oil in the world in 2000, after soybean and palm oil. It is the world's second-leading source of protein meal after soybean (Heuzé et al., 2017). Front line demonstration (FLDs) is introduced by the
Indian Council of Agricultural Research, New Delhi with inception of technology mission of pulse and oil seed crops during mid-eighties. The field demonstration conducted under the close supervision of scientist of the KVKs. Poonia and Pithia (2011) concluded that the yield gap between conventional practices and improved package of practices was much higher ranging from $21 \mathrm{~kg} / \mathrm{ha}$ to $349 \mathrm{~kg} / \mathrm{ha}$. Singh et al., (2014) concluded that front line demonstration increase the productivity due to adoption of interventions like seed testing, use of high yielding varieties, seed treatment, fertilizer application and plant protection 
measure on rapeseed. Balai et al., (2012) revealed that front line demonstration on rapeseed -mustard an average yield in improved package and practices(IP) under irrigated conditions ranges from 15.89 to $17.53 \mathrm{q} / \mathrm{ha}$ whereas in farmers practice (FP) ranges from 12.53 to $13.12 \mathrm{q} / \mathrm{ha}$. Tiwari et al., (2017) revealed that the FLD on Indian mustard registered 35.0 percent higher yield over farmer's practice on an average and highest yield (18.65 q ha-1) was recorded in 2015-16 in FLD with variety NDRE - 4, which was 52.0 per cent more yield over the farmer's practice $(12.20 \mathrm{q}$ ha-1). The technology demonstrated that the cultivation of high yielding varieties of mustard viz. Bhagirathi (RW-351), Sanjukta asech (4C-63/II), Jhumka (NC-1), Seeta (B-85) and Binoy (B-9) shows percentage increase of 57.51, 53.57, 50.97, 35.00 and 24.44 respectively over local check (Sagar and Chandra, 2004). Keeping the importance of FLDs, the KVK, Namsai conducted demonstrations on rapeseed at farmers field in rabi season during the year 2013-14, 2014-15 and 2015-16.

\section{Materials and Methods}

The present study was conducted by the Krishi Vigyan Kendra, Namsai of Arunachal Pradesh, India continuously for three consecutive years (Rabi 2013-14, 2014-15 and 2015-16) to assess the impact of improved technology of rapeseed under real farm situations. In general soil of the area under study was sandy loam with medium fertility status. The component demonstration of front line technology in rapeseed was comprised of improved variety TS-36, TS-38 and TS-46, proper seed rate and improved sowing method, balance dose of biofertilizer (PSB 2kg/ha + Azotobacter $2 \mathrm{~kg} / \mathrm{ha}$ ), use of Trichoderma @ of $5 \mathrm{~g} / \mathrm{kg}$ of seed as seed treatment, weed management and protection measure. In the demonstration, one control plot was also kept where farmers practices was carried out. The aim of the FLDs was to demonstrate the impact of research emanated production technologies that of improved varieties, seed treating chemicals, Integrated Nutrient management, Integrated pest Management and strategies to economize water application and prevent the crop from abiotic stress. The FLD was conducted to study the technology gap between the potential yield and demonstrated yield, extension gap between demonstrated yield and yield under existing practice and technology index.

The yield data were collected from both the demonstration and farmers practice analyzed by using simple statistical tools. Site selection, farmers selection were considered as suggested by Choudhary (1999). The observation on seed yield per ha was recorded. Other parameters like harvest index, technology index were worked out as suggested by Kadian et al., (1997). The gross return, net return, cost of cultivation and benefit cost ration were also calculated. Training to the farmers of respective villages was imparted before conducting the demonstrations with respect to envisaged technological.

The data were collected from both demonstration plots and control plots and finally, the extension gap, technology gap, technology index with the cost benefit ratio (Samui et al., 2000) were calculated as follows:

Technology Gap = Potential yield Demonstration yield

Extension Gap = Demonstration yield Farmer yield

Technology Index $=$ Potential yield - Demonstration yield Potential yield 


\section{Results and Discussion}

The result of the study for three years in different villages of Namsai district indicated that, Grain Yield, technology gap, Extension gap, Technology index of Rapeseed in district Namsai was presented in Table 1 and Fig. 1 for Rabi season during the year 2013-14, 2014-15 and 2015-16.

\section{Yield}

The data results revealed that the front line demonstration on rapeseed an average yield was recorded $9.47 \mathrm{q} / \mathrm{ha}, 9.44 \mathrm{q} / \mathrm{ha}$ and 9.03 q/ha under demonstrated plots TS-36, TS-38 and TS-46 variety, as compare to farmers practice $6.60 \mathrm{q} / \mathrm{ha}$. This results clearly indicated that the higher average grain yield in demonstration plots over the years compare to local check was due to knowledge and adoption of full package of practices i.e. appropriate varieties such as TS-36, TS-38 and TS-46 timely sowing, improved sowing method, seed treatment with Trichoderma @ $5 \mathrm{~g} / \mathrm{kg}$ of seed, use of balanced dose of biofertilizer (PSB 2kg/ha + Azotobacter $2 \mathrm{~kg} / \mathrm{ha}$ ), method and time of sowing, timely weed management and need based plant protection.

The average yield of rapeseed increased from 36 to 43 percent. The yield of rapeseed could be increased over the yield obtained under farmers practices (use of non descriptive local variety, no use of the balanced dose of fertilizer, untimely sowing and no control measure adopted for pest management) of rapeseed cultivation. More or less similar results were also reported by Ojha et al., (2020) that TS-67 variety of rapeseed/toria considered in the demonstration plot produced the maximum seed $(8.1 \mathrm{q} / \mathrm{ha})$ in Udalguri, Assam. Whereas, the average demonstration yield rapeseed/mustard ( $c v$-Bio 902) was recorded to be $17.53 \mathrm{q} / \mathrm{ha}$ by Balai et al.,
(2012) and mustard (var. Pusa jaikisan/pusa bold) recorded to be $155.67 \mathrm{q} / \mathrm{ha}$ by Singh $e t$ al., (2014). The yield enhancement in rapeseed-mustard crop in frontline demonstration has been documented by Mitra and Samajdar (2010) in tarai zone of West Bengal.

\section{Technology gap}

The technology gap the differences between potential yield and yield of demonstration plots were 2.53, 2.56 and $2.97 \mathrm{q} /$ ha for TS-36, TS-38 and TS-46 variety respectively. The technology gap of rapeseed/toria (var. TS-67) was $1.9 \mathrm{q} / \mathrm{ha}$ by Ojha et al., (2020) and rapeseed/mustard ( $c v$-Bio 902) ranging between 2.47-4.11q/ha by Balai et al., (2012). The technology gap observed may be attributed to dissimilarity in the soil fertility status, agricultural practices and local climatic situation. Mukherjee (2003) has also opined that depending on identification and use of farming situation, specific interventions may have greater implications in enhancing system productivity.

\section{Extension gap}

Extensions gap of 2.87, 2.84 and $2.43 \mathrm{q} / \mathrm{ha}$ were observed for TS-36, TS-38 and TS-46 variety respectively which emphasized the need to educate the farmers through various extensions means i.e. front line demonstration for adoption of improved production and protection technologies, to revert the trend of wide extension gap. More or less similar findings reported by Ojha et al., (2020) that rapeseed/toria variety TS-67 was $1.8 \mathrm{q} / \mathrm{ha}$ in Udalguri, Assam. Balai et al., 2012 reported that extension gap of rapeseed/mustard ( $c v$ Bio 902) 3.36-4.41q/ha during the period of study. More and more use of latest production technologies with high yielding varieties will subsequently change this alarming trend of galloping extension gap. 
Table.1 Grain yield, technology gap, extension gap, technology index of rapeseed under FLDs

\begin{tabular}{|c|c|c|c|c|c|c|c|c|c|c|c|}
\hline \multirow[t]{2}{*}{ Year } & \multirow[t]{2}{*}{ Crop } & \multirow[t]{2}{*}{ Variety } & \multirow{2}{*}{$\begin{array}{c}\text { Area } \\
\text { (ha) }\end{array}$} & \multirow{2}{*}{$\begin{array}{c}\text { No of } \\
\text { farmers }\end{array}$} & \multicolumn{3}{|c|}{ Grain Yield (q/ha) } & \multirow{2}{*}{$\begin{array}{c}\% \\
\text { increase } \\
\text { over FP }\end{array}$} & \multirow{2}{*}{$\begin{array}{l}\text { Technology } \\
\text { Gap (q/ha) }\end{array}$} & \multirow{2}{*}{$\begin{array}{c}\text { Extension } \\
\text { Gap } \\
\text { (q/ha) }\end{array}$} & \multirow{2}{*}{$\begin{array}{c}\text { FP } \\
\text { Index } \\
(\%)\end{array}$} \\
\hline & & & & & Potential & $\mathbf{R P}$ & FP & & & & \\
\hline 2013-14 & Rapeseed & TS-36 & 10 & 30 & 12 & 9.47 & 6.60 & 43.49 & 2.53 & 2.87 & 21.08 \\
\hline $2014-15$ & Rapeseed & TS-38 & 12 & 37 & 12 & 9.44 & 6.60 & 43.03 & 2.56 & 2.84 & 21.33 \\
\hline $2015-16$ & Rapeseed & TS-46 & 3 & 8 & 12 & 9.03 & 6.60 & 36.82 & 2.97 & 2.43 & 24.75 \\
\hline \multicolumn{3}{|c|}{ Average } & 8.33 & 25 & 12 & 9.31 & 6.60 & 41.11 & 2.69 & 2.71 & 22.39 \\
\hline
\end{tabular}

Table.2 Economic analysis of the recommended practices of rapeseed under FLDs

\begin{tabular}{|c|c|c|c|c|c|c|c|c|c|c|c|}
\hline \multirow[t]{2}{*}{$\begin{array}{c}\text { Rapeseed } \\
\text { variety }\end{array}$} & \multicolumn{2}{|c|}{ Yield (q/ha) } & \multirow[t]{2}{*}{$\begin{array}{c}\% \text { increase } \\
\text { over FP }\end{array}$} & \multicolumn{2}{|c|}{$\begin{array}{c}\text { Gross Expenditure } \\
\text { (Rs/ha) }\end{array}$} & \multicolumn{2}{|c|}{$\begin{array}{l}\text { Gross Return } \\
\text { (Rs/ha) }\end{array}$} & \multicolumn{2}{|c|}{$\begin{array}{l}\text { Net Returns } \\
\text { (Rs/ha) }\end{array}$} & \multicolumn{2}{|c|}{ B:C Ratio } \\
\hline & $\mathbf{R P}$ & FP & & $\mathrm{RP}$ & FP & $\mathrm{RP}$ & FP & $\mathbf{R P}$ & FP & $\mathbf{R P}$ & FP \\
\hline TS-36 & 9.47 & 6.60 & 43.49 & 16,285 & 14,785 & 23675 & 16500 & 7390 & 1715 & 1.45 & 1.12 \\
\hline TS-38 & 9.44 & 6.60 & 43.03 & 16,485 & 14,985 & 23600 & 16500 & 7115 & 1515 & 1.43 & 1.10 \\
\hline TS-46 & 9.03 & 6.60 & 36.82 & 16,585 & 15,085 & 22575 & 16500 & 5990 & 1415 & 1.36 & 1.09 \\
\hline Average & 9.31 & 6.6 & 41.11 & 16451.67 & 14951.67 & 23283.33 & 16500 & 6831.67 & 15548.33 & 1.41 & 1.10 \\
\hline
\end{tabular}

Fig.1 Impact of Front line demonstration on \% increase over FP, Technology Gap (q/ha), Extension Gap (q/ha) and FP Index (\%) of rapeseed var. TS-36, TS-38 and TS-46

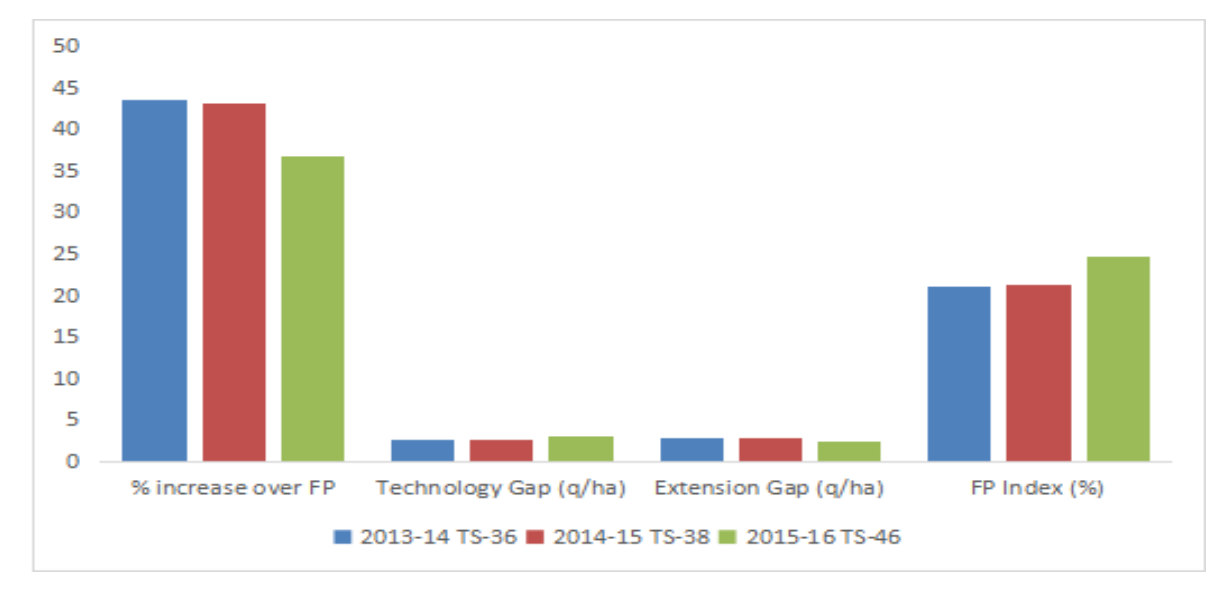




\section{Technology index}

The technology index shows the feasibility of the demonstrated technology at the farmers field. The technology index varied from $21.08 \%, 21.33 \%$ and $24.755 \%$ for TS-36, TS38 and TS-46 variety respectively (Table 1 ). The increase in percentage of yield was ranging between $26.82-33.61 \%$ during the three years of study of rapeseed/mustard ( $c v$ Bio 902) (Balai et al., 2012). Higher technology index reflected the insufficient extension services for transfer of technology. The lower value of technology index shows the efficacy and excellent performance of technological interventions. This will accelerate the adoption of demonstrated technical intervention to increase the yield performance of rapeseed. The FLD produces a significant positive result and provided the researcher an opportunity to demonstrate the productivity potential and profitability of the latest technology (intervention) under real farming situation which they have been advocating for long time.

\section{Economic return}

The inputs and outputs prices of commodities prevailed during the study of demonstrations were taken for calculating gross return, cost of cultivation, net return and benefit: cost ratio (Table 2). The cultivation of rapeseed variety of TS-36, TS-38 and TS-46 under improved technologies gave higher net return per hectare of Rs. 7390, 7115 and5990 respectively as compared to farmers practices. The benefit cost ratios of rapeseed variety of TS-36, TS-38 and TS-46 under improved technologies were $1.45,1.43$ and 1.36 as compared to $1.12,1.10$ and 1.09 under farmers practices. This may be due to higher yields obtained under improved technologies compared to local check (farmers practice). This finding is in corroboration with the findings of Ojha et al., (2020), Singh et al., (2015) and Balai et al., (2012).
In conclusion, the front line demonstration (FLDs) play a very important role to disseminate recommended technologies, it shows the potential of technology resulting in an increased in yield at farmers level. These practices may be popularized in this area by the extension agency to bridge the higher extension gaps. This also improved the relationship between farmers and scientist and built confidence between them. Under sustainable agricultural practices, with this study it is concluded that the FLDs programmes were effective in changing attitude, skill and knowledge of farmers to adopt improved package and practices and HYV of rapeseed.

\section{Acknowledgement}

Authors are thankful to ICAR-Krishi Vigyan Kendra Namsai (Arunachal Pradesh) for providing necessary budget to conduct the frontline demonstrations on rapeseed with the intend to raise the productivity and livelihood.

\section{References}

Balai, C. M; Meena, R.P; Meena, B. L. and Bairwa, R. K. 2012. Impact of Front Line Demonstration on RapeseedMustard Yield Improvement. Indian Res. J. Ext.Edu., 12( 2), p 115

Chaudhary, B.N. 1999. KVK-A guide for KVK managers. Publication, Divi. of Agril .Ext.,, CAR. pp 73-78

Heuzé, V.; Tran, G.; Sauvant, D.; Lessire, M. and Lebas, F. 2017. Rapeseed meal. Feedipedia, a programme by INRA, CIRAD, AFZ an FAO. https://www.feedipedia.org/node/5 2. 14,55 .

Kadian, K.S; Sharma, R and Sharma, A. K. 1997. Evaluation of front line demonstration trials on oilseeds in Kangra Vally of Himanchal Pradesh. Ann. Agric. Res., 18: 40.

Mitra, B. and Samajdar, T. 2010. Yield gap 
analysis of rapeseed-mustard through FLD. Agril. Ext. Review. 22 (2),16-17.

Mukharjee, N. 2003. Participatory learning and action. Concept publishing company, New Delhi, India. pp 63-65

Ojah, I; Borah, D; Rabha, H and Deka, P. 2020. Performance of Toria using INM under Late Sown Rainfed Condition in Rice Fallow of Udalguri District of Assam, India. International Journal of Current Microbiology and Applied Sciences. 9 (7):2799-2805

Poonia, T.C and Pithia, M.S. 2011. Impact of front line demonstrations of chickpea in Gujarat. Legume Res, 34(4) : 304-307.

Sagar, R.L. and Chandra, G. 2004. Evaluation of Frontline Demonstration on Mustard in Sunderbans, West Bengal. Indian Journal of Extension Education. 40 (3\&4): 96-97.

Samui, S.K., Mitra, S., Roy, D.K., Mandal,
A.K. and Saha, D. 2000. Evaluation of front line demonstration on groundnut. Journal of the Indian Society of Costal Agriculture Research, 18(2): 180-183.

Singh, Dhananjai; Patel, A.K; Baghel, M.S; Singh, Alka and Singh, A.K. 2014.Technological Intervention for Reducing the Yield Gap of Chick Pea (Cicer arietinum L.) in Sidhi District of M.P. International Journal of Advanced Research in Management and Social Sciences, 3(3): 117-122.

Tiwari, D. K; Chandra, V; Pandey, S. K; Sahay, R; Singh A and Singh A.K. 2017. Effect of front line Demonstration on Production, Profitability, and Social impact on Mustard cultivation. Bulletin of Environment, Pharmacology and Life Sciences. 6(3): 134-137.

\section{How to cite this article:}

Sonowal Bora, M., D. Sasmal, Debasish Borah and Kalita, H. 2020. Impact of Front Line Demonstration on the Yield and Economics of Rapeseed under Rainfed Condition in Namsai District of Arunachal Pradesh, Inida. Int.J.Curr.Microbiol.App.Sci. 9(09): 3422-3427. doi: https://doi.org/10.20546/ijcmas.2020.909.424 